\title{
Tumour that challenged diagnosis: mandibular myofibroma
}

\author{
Mahesh Chinta, ${ }_{1}^{1}$ A J Sai Sankar, ${ }^{2}$ Sribala Naga Gantha, ${ }^{1}$ Pratej Kiran Kanumuri ${ }^{3}$
}

${ }^{1}$ Department of Pedodontics and Preventive Dentistry, Panineeya Mahavidyalaya Institute of Dental Sciences and Research Centre,

Hyderabad, Telangana, India ${ }^{2}$ Department of Pedodontics and Preventive Dentistry, Sibar Institute of Dental Sciences,

Guntur, Andhra Pradesh, India ${ }^{3}$ Panineeya Institute of Dental Sciences and Hospital, Hyderabad, Telangana, India

\section{Correspondence to} Dr Pratej Kiran Kanumuri, pratejkiran@gmail.com

Accepted 29 September 2016

CrossMark

To cite: Chinta $\mathrm{M}$ Sankar AJS, Gantha SN, et al. BMJ Case Rep Published online: [please include Day Month Year] doi:10.1136/bcr-2016217890

\section{DESCRIPTION}

Myofibroma is a rare, benign, nodular tumour of soft tissues, bones or internal organs. It was first described by Stout in 1954 as congenital generalised fibromatosis and it was renamed by Chung et al as 'infantile myofibromatosis' as the onset of the disease is at a young age. ${ }^{1}$ Later Smith et al introduced the term 'myofibroma' and suggested that these lesions may not be exclusively paediatric. ${ }^{2}$

Myofibroma represents the most common fibrous tumour of infancy, predominantly in the head and neck region. However, its involvement in jaws is rare. This disease presents as a locally invasive, hard painless mass unless it is secondarily infected. The lesion is considered to be completely benign but there is a potential for it, being confused with more aggressive spindle cell tumours. ${ }^{3}$ So it is very important to make an accurate diagnosis of such lesions, because of their common clinical and radiographical features. Advanced diagnostic options such as immunohistochemistry should be explored, which may give definitive diagnosis.

This is a case report of a 4-year-old boy who came to the outpatient department with a diagnosis of fibrosarcoma for a swelling in the lingual surface of mandibular anterior. History revealed that patient went to the dentist with symptom of swelling in the floor of the mouth since 15 days. The patient's parents reported that swelling was gradual in onset and was not associated with pain or pus discharge. Medical and dental histories were unremarkable. Incisional biopsy was performed and a diagnosis of fibrosarcoma was made by the dentist. After a week the patient reported to the department of paediatric dentistry with this history. On extraoral examination, bilateral palpable submandibular lymph nodes which were $1 \times 1 \mathrm{~cm}$ in size, soft in consistency and tender on palpation were observed. On intraoral examination a $2 \times 3 \mathrm{~cm}$ sized lesion, which was oval in shape was observed on the lingual side of primary mandibular anterior in relation to $71,72,73,81$ (ISO system) crossing the midline and extending over the lingual fraenum. The mucosa over the growth was erythematous. On palpation the growth was sessile and firm in consistency, non-compressible, reducible, fluctulent and tender on palpation (figure 1).

Orthopantomogram showed evidence of a welldefined unilocular radiolucency in the mental region of the mandible extending from the mesial aspect of permanent canine follicle to the other side indicating erosive changes (figure 2).

All the haematological findings were in normal limits. An incisional biopsy was performed and histological examination revealed the presence of spindle-shaped cells with prominent nucleus and the cells were arranged in a 'lace-like pattern' (figure 3)

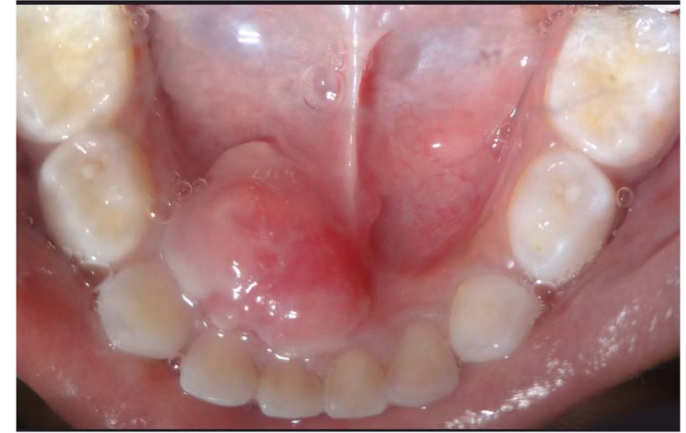

Figure 1 Intraoral picture showing diffuse swelling in the floor of the mouth.

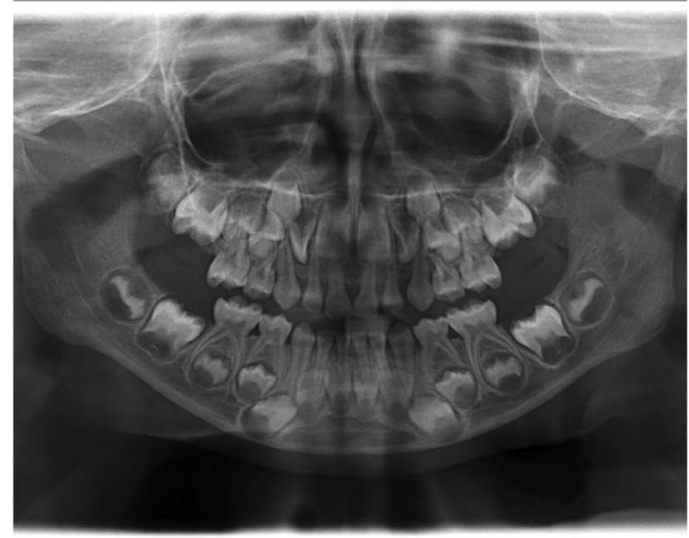

Figure 2 Orthopantomogram showing well-defined unilocular radiolucency in the mental region of mandible.

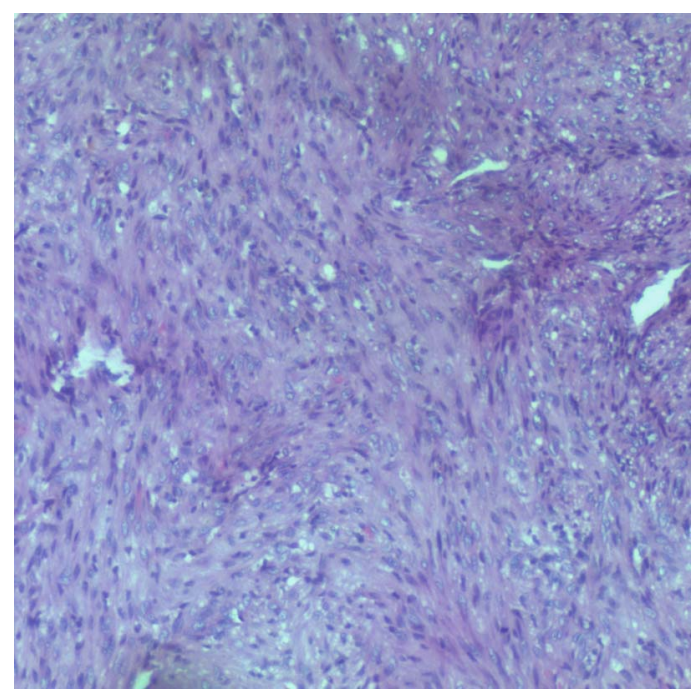

Figure 3 Histopathological picture showing a 'lace-like' cell pattern. 


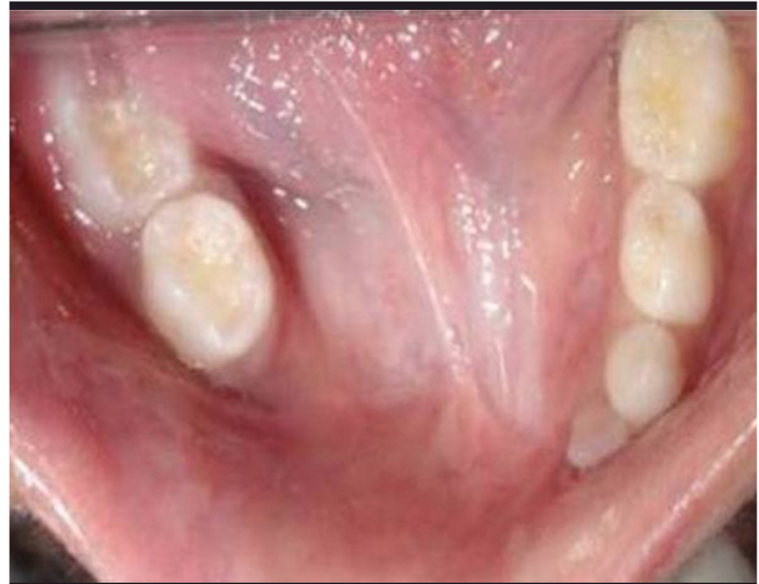

Figure 4 Postoperative intraoral picture showing complete surgical excision of the tumour en bloc along with wedge of the mandible.

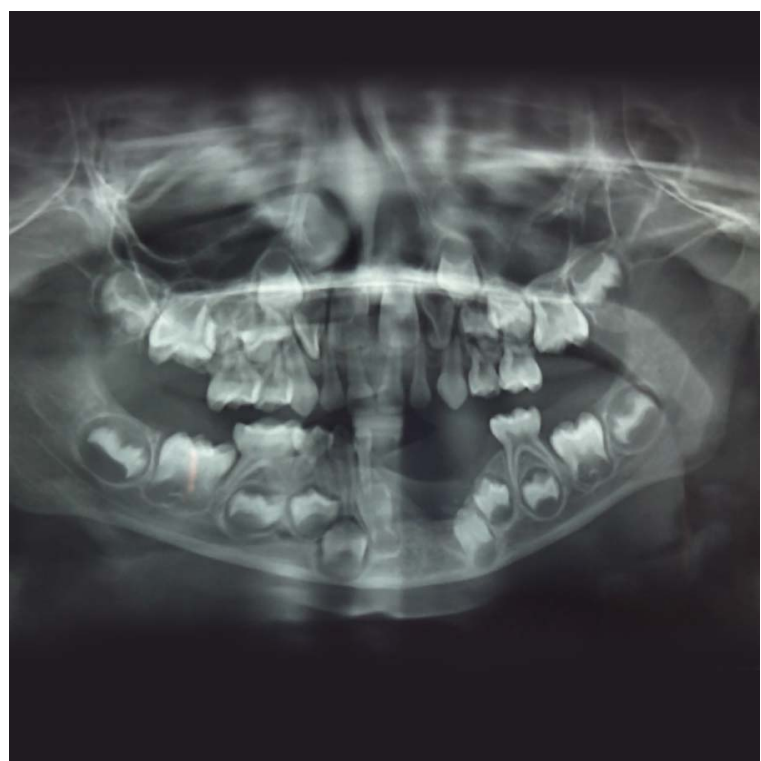

Figure 5 Postoperative orthopantomogram showing the resected anterior segment of the mandible along with tooth buds.

suggesting the differential diagnosis of leiomyoma or myofibroma which was contrary to the previous diagnosis. To make an accurate diagnosis immunohistochemical analysis was performed. The test was positive for smooth muscle actin and negative for desmin, thus the final diagnosis of myofibroma was made. Complete surgical excision of the tumour en bloc along with wedge of the mandible (figure 4) and tooth buds of 31,32,41 (ISO system) was performed under general anaesthesia (figure 5). Prosthetic rehabilitation of missing teeth with acrylic removable partial denture was carried out after 2 months (figure 6).

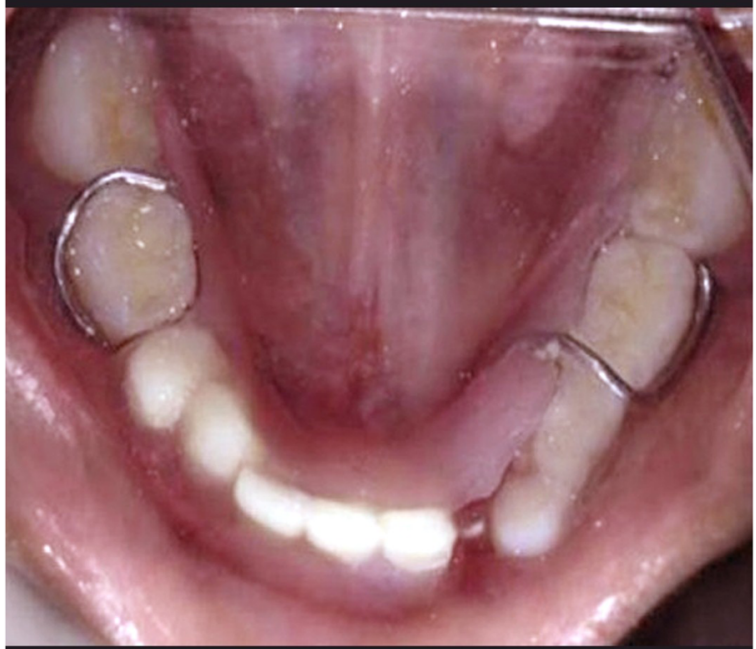

Figure 6 Postoperative intraoral picture with acrylic removable partial denture.

The patient was followed up for a year and no recurrence was observed.

\section{Learning points}

- Myofibroma is an uncommon spindle cell neoplasm rarely found in the oral cavity especially in the mandible.

- Immunohistochemical staining is an indispensable tool to identify the nature of neoplastic cells and make an accurate diagnosis in cases of myofibroma.

- Myofibromas are unencapsulated tumours, treatment should include complete excision of the lesion along with a border of the clinically normal bone.

- Early diagnosis of the lesion with advanced techniques is mandatory to eliminate bias in diagnosis and for proper treatment planning.

Contributors MC was involved in carrying out the case. AJSS was involved in guiding the case. SNG was involved in the preparation of the manuscript. PKK was involved in the preparation of the manuscript.

Competing interests None declared.

Patient consent Obtained.

Provenance and peer review Not commissioned; externally peer reviewed.

\section{REFERENCES}

1 Chung EB, Enzinger FM. Infantile myofi bromatosis. Cancer 1981;48:1807.

2 Smith KJ, Skelton HG, Barrett TL, Lupton GP, Graham JH. Cutaneous myofibroma. Mod Pathol 1989;2:603-9.

3 Sabri A, Korban Z, Rizk SA, et al. Parapharyngeal space myofibroma: a case report and review of the literature. SM J Surg 2015;1:1002. 
Copyright 2016 BMJ Publishing Group. All rights reserved. For permission to reuse any of this content visit http://group.bmj.com/group/rights-licensing/permissions.

BMJ Case Report Fellows may re-use this article for personal use and teaching without any further permission.

Become a Fellow of BMJ Case Reports today and you can:

- Submit as many cases as you like

- Enjoy fast sympathetic peer review and rapid publication of accepted articles

- Access all the published articles

- Re-use any of the published material for personal use and teaching without further permission

For information on Institutional Fellowships contact consortiasales@bmjgroup.com

Visit casereports.bmj.com for more articles like this and to become a Fellow 